\title{
Potential of the Dithiocarbimate Fungicides on the Control of Coffee Leaf Rust and Asian Soybean Rust
}

\author{
Lucas Fagundes da Silva ${ }^{1}$, Laércio Zambolim ${ }^{1}$, Antônio Eustáquio Carneiro Vidigal ${ }^{2}$ \\ $\&$ Mayura Marques Magalhães Rubinger ${ }^{2}$ \\ ${ }^{1}$ Departamento de Fitopatologia, Universidade Federal de Viçosa, Viçosa, Minas Gerais, Brazil \\ ${ }^{2}$ Departamento de Química, Universidade Federal de Viçosa, Viçosa, Minas Gerais, Brazil \\ Correspondence: Laércio Zambolim, Biocafé/Bioagro, Universidade Federal de Viçosa, Viçosa 36570-900, \\ Minas Gerais, Brazil. E-mail: laerciozambolim@gmail.com
}

Received: July 25, 2021

Accepted: August 31, 2021

Online Published: September 15, 2021

doi:10.5539/jas.v13n10p131

URL: https://doi.org/10.5539/jas.v13n10p131

\begin{abstract}
Coffee leaf rust (Hemileia vastatrix) and Asian soybean rust (Phakopsora pachyrhizi) are diseases that cause great losses in the productivity of these crops, not only in Brazil but on a global scale. Coffee and soybean varieties grown are susceptible to these diseases. Thus, it is necessary to search for efficient compounds for their chemical control, mainly from the group of protectors or residuals so that they can be formulated with systemic fungicides to control the diseases. This allows not only the efficient management of diseases but also the prevention of the emergence of resistant mutants in the populations of these pathogens. In this context, the present study aimed to evaluate the sensitivity and effect of bis(N-R-sulfonyldithiocarbimato)zincate(II) salts fungicides on the epidemiological components of pathosystems coffee $\times H$. vastatrix and soybean $\times P$. pachyrhizi. Initially, four zinc(II) complexes salts (1A, 2A, 1B, and 2B) with N-R-sulfonyldithiocarbimates were synthesized. In the first experiment, the in vitro sensitivity of $H$. vastatrix and $P$. pachyrhizi was studied for the four compounds synthesized and mancozeb at $0.5,5.0,50.0,100.0$ and $200.0 \mu \mathrm{mol} \mathrm{L}^{-1}$. All the compounds synthetized in this study had inhibitory effects on H. vastatrix and P. pachyrhizi. In the greenhouse it was studied the effect of $b i s(\mathrm{~N}-\mathrm{R}$-sulfonyldithiocarbimato)zincate(II) salts on the epidemiological components of coffee leaf rust and Asian soybean rust. For the pathosystem coffee $\times H$. vastatrix, there were no differences in the values obtained for the bis(N-R-sulfonyldithiocarbimato)zincate(II) salts and mancozeb for the latent period. For the sporulated lesion variable, the control treatment had a mean value of 149.0 lesions/leaf, differing significantly from the other treatments. The mean value of compound $2 \mathrm{~B}$ was estimated as 25.0 lesions/leaf, differing significantly from treatments $1 \mathrm{~A}, 1 \mathrm{~B}, 2 \mathrm{~B}$, and mancozeb. Treatments $1 \mathrm{~A}, 1 \mathrm{~B}, 2 \mathrm{~B}$, and mancozeb did not differ significantly from each other. For the Asian soybean rust, the area under the disease progress curve had a mean value of 75.8 for the control, while for the $2 \mathrm{~A}$ treatment the value was 4.1, differing from the other compounds. The treatments $1 \mathrm{~A}, 1 \mathrm{~B}, 2 \mathrm{~A}$, and mancozeb did not differ significantly from each other. In conclusion, compounds $1 \mathrm{~A}, 2 \mathrm{~A}$, and $1 \mathrm{~B}$ were more efficient in the control of the coffee leaf rust, while compound $2 \mathrm{~A}$ was efficient in the control of the Asian soybean rust.
\end{abstract}

Keywords: Hemileia vastatrix, Phakopsora pachyrhizi, chemical control, multisite fungicides, dithiocarbimate group

\section{Introduction}

The increase in the world population has driven the search for new agrochemicals to ensure the sustainable production of food. Such agrochemicals aim to maintain the productivity potential of crops, not only in Brazil but on a global scale. In Brazilian agribusiness, the production of coffee (Coffea arabica L.) and soybean (Glycine $\max$ L. Merryl) correspond 45.3 milions bags and 120.3 milions tons, respectively (CONAB, 2019). Among the main factors capable of limiting coffee and soybean production in the Brazil and world, rust diseases stand out. The fungus Hemileia vastatrix Berk. \& Br., the causal agent of coffee leaf rust, causes damage that can affect up to $50 \%$ of coffee production (Zambolim, 2016). Besides, the fungus Phakopsora pachyrhizi, the causal agent of Asian soybean rust, causes damage of up to $90 \%$ to soybean crops (Yorinori et al., 2005). Management strategies for these diseases are based on a combination of specific- site and multi-site fungicides (Godoy et al., 2016; Zambolim, 2016; Reis et al., 2021). Usually, for the coffee leaf rust, strategies are based on 
the use of triazole fungicides formulated with strobilurins combined with multi-site copper fungicids. However, copper is a heavy metal that can accumulate in the environment, despite being crucial in the control not only of coffee leaf rust but also of other diseases and as a nutrient (Sousa et al., 2017). For the Asian soybean rust, chemical control strategies usually adopt triazoles, strobilurins, and dicarboxamides associated with multi-site chlorothalonil or mancozeb (Ponce et al., 2019). The use of multi-site fungicides has become indispensable to reduce the selection pressure on the pathogen population. Several studies of multiple resistance to triazole, strobilurin, and dicarboxamide groups are reported in the literature (Schmitz et al., 2014; Twizeyimana \& Hartman, 2017; Simões et al., 2018). Currently, the companies have been using multi-site fungicides developed in the 1950-60s (Zambolim \& Caixeta, 2018; Reis et al., 2021).

Several studies have shown, in vitro, the inhibition of mycelial growth of the fungi Colletotrichum gloeosporioides and Botrytis cinerea by new compounds belonging to the dithiocarbimate group (Bottega et al., 2013; Oliveira et al., 2015). The dithiocarbimate group is analogous to the dithiocarbamates but does not have a commercial formulation. The dithiocarbamates are widely used in agriculture, and their leading representative is mancozeb (Zambolim, 2008). Such groups differ chemically only by the existence of a double bond between the carbon and nitrogen atoms. In this context, researches seeking for new fungicide compounds that are highly efficient in disease control and have good acceptance by the society are vital. Dithiocarbimates are promising compounds since they have a multi-site action, either alone or as compound formulations with systemic fungicides, in the disease control of plants. The first study, involving this group of chemical compounds, in the disease control was conducted by Vidigal et al. (2019). The authors reported for the first time the effect of new heteroleptic nickel(II) complexes with aromatic and aliphatic sulfonyldithiocarbimates, triphenylphosphine and 1,2-bis(diphenylphosphine)ethane on the uredospore germination of $H$. vastatrix and $P$. pachyrhizi; however, their experiments were restricted to in vitro assays, and the control efficiency of this fungicide group in controlled conditions in vivo is unknown.

This work is justified due to the fact that, coffee leaf rust and Asian soybean rust can severely damage both crops. In addition, there is a great need to find new protective fungicide compounds to be used in mixtures with systemic and mesostemic fungicides, aiming to reduce the emergence of resistant mutants of specific mechanism of action fungicides, used in disease control.

Thus, this study aimed to evaluate the sensitivity and effect of bis(N-R-sulfonyldithiocarbimato)zincate(II) salts on the epidemiological components of the pathosystems coffee $\times H$. vastatrix and soybean $\times P$. pachyrhizi.

\section{Material and Methods}

\subsection{Synthesis of N-R-Sulfonyldithiocarbimate Potassium Salts}

The synthesis of the four N-R-sulfonyldithiocarbimate potassium salts consisted of two stages, following the procedures described by Amin (2011).

The first stage included the production of the precursors of potassium dithiocarbimates. In a round-bottom flask, $10,000 \mu \mathrm{mol}$ of methanesulfonamide or 4-chlorobenzenesulfonamide; $20 \mathrm{~mL}$ of $N, N$-dimethylformamide; 0.60 $\mathrm{mL}$ of carbon disulfide $(10,000 \mu \mathrm{mol})$ and $1.32 \mathrm{~g}$ of $\mathrm{KOH}(20,000 \mu \mathrm{mol})$ were added. The reaction mixture was kept under stirring until the consumption of $\mathrm{KOH}$, indicating the end of the reaction. Then, $20 \mathrm{~mL}$ of absolute ethanol was added, and the round-bottom flask was placed in an ice bath.

The yellow precipitates resulting from the reaction were filtered and then washed with ethanol, ethyl acetate, and diethyl ether. Soon after, the precipitates were left in a desiccator for 24 hours. At the end of this reaction, the potassium methylsulfonyldithiocarbimate and the potassium 4-chlorophenylsulfonyldithiocarbimate were obtained as products.

The second stage consisted of the stabilization of the dithiocarbimates from the formation of zinc complexes. To perform the synthesis of the zinc complexes, $1,000 \mu \mathrm{mol}$ of potassium dithiocarbimate, $20 \mathrm{~mL}$ of $\mathrm{MeOH} / \mathrm{H}_{2} \mathrm{O}$ solution $(1: 1 \mathrm{v} / \mathrm{v})$, and $500 \mu \mathrm{mol}$ of zinc sulfate dissolved in $4 \mathrm{~mL}$ of $\mathrm{H}_{2} \mathrm{O}$ were added in a round-bottom flask. The reaction mixture remained under stirring for one hour. Then $1,000 \mu \mathrm{mol}$ of tetraphenylphosphonium chloride or tetrabutylammonium bromide dissolved in water were added, drop by drop. The resulting precipitate was filtered in a funnel with a porous porcelain plate, washed five times, and then dried under reduced pressure for 24 hours. In this way, " 1 " is 4-chlorophenyl group and " 2 " is methyl group, white group "B" has the cation tetrabutylammonium and group " $\mathrm{A}$ " has the cation tetraphenylphosphonium. The four synthesized compounds were named as follows: tetraphenylphosphonium bis(4-chlorophenylsulfonyldithiocarbimate)zincate(II) (1A); tetraphenylphosphonium, $\quad$ bis(methylsulfonyldithiocarbimate)zincate(II) $\quad(2 \mathrm{~A}) ; \quad$ tetrabutylammonium 
bis(4-chlorophenylsulfonyldithiocarbamate)zincate(II)

bis(chlorophenylsulfonyldithiocarbimate)zincate(II) (2B).
(1B);

and

tetrabutylammonium

\subsection{Production of $H$. vastatrix and P. pachyrhizi Uredospores}

Coffee seeds of the variety Caturra lineage IAC 144 were sown in the sand and kept at $28{ }^{\circ} \mathrm{C}$. After thirty days, the seedlings were transplanted to $2.0 \mathrm{dm}^{3}$ vessels and cultivated for 45 days. Then, the third pair of leaves were inoculated with the H. vastatrix uredospores race II from the Plant Protection Laboratory, Department of Plant Pathology, Federal University of Viçosa, state of Minas Gerais, Brazil. The plants remained for 48 hours in a dew chamber in the dark at $22{ }^{\circ} \mathrm{C}$ during the entire experiment and were kept in a growth chamber with a 12-hour photoperiod for 35 days until the production of uredospores.

The uredospores of P. pachyrhizi from the Plant Protection Laboratory were inoculated at the V5 phenological stage in the soybean variety TMG 132. Subsequently, the plants in $2.0 \mathrm{~cm}^{3}$ vessels were kept for 48 hours in the dew chamber, in the dark, and at $22{ }^{\circ} \mathrm{C}$. After inoculation, the plants were placed in a growth chamber with a 12-hour photoperiod for 15 days to produce uredospores.

The produced uredospores were collected. One part was kept in a desiccator at $5{ }^{\circ} \mathrm{C}$ and $50 \%$ relative humidity and the other part in an ultra-freezer at $-80^{\circ} \mathrm{C}$.

\subsection{The Sensitivity of H. vastatrix and P. pachyrhizi to the bis(N-R-Sulfonyldithiocarbimato)Zincate(II) Salts}

Two in vitro experiments were performed in a completely randomized design, with three replicates. The treatments were composed of mancozeb (Sigma Aldrich ${ }^{\circledR}$ ) compounds 1A, 2A, 1B, and 2B at 0.5, 5.0, 50.0, 100.0, and $200.0 \mu \mathrm{mol} \mathrm{L}^{-1}$, in addition to the controls with water agar, DMSO at $0.5 \%(\mathrm{v} / \mathrm{v})$, and Tween 80 at $0.5 \%(\mathrm{v} / \mathrm{v})$.

The compounds 1A, 2A, 1B, and 2B $(0.01 \mathrm{~g})$ were dissolved into $10 \mathrm{~mL}$ of dichloromethane, and the volume corresponding to each concentration was transferred to $50 \mathrm{~mL}$ round-bottom flasks. The solvent was evaporated under reduced pressure. DMSO and Tween 80 were added to each round-bottom flask at $0.5 \%(\mathrm{v} / \mathrm{v})$.

These solutions were homogenized in $2 \%$ water agar, and the mixtures were distributed in $60 \times 15 \mathrm{~mm}$ Petri dishes. A $0.1 \mathrm{~mL}$ aliquot of $10^{5}$ uredospores $\mathrm{mL}^{-1}$ from H. vastatrix or P. pachyrhizi was spread on each plate with a Drigalski spatula. The plates were kept at $25{ }^{\circ} \mathrm{C}$ under continuous darkness in a BOD Incubator for 24 hours. After this period, the germination of 100 uredospores per plate was randomly evaluated by optical microscopy at 400-fold magnification. The mean values of the in vitro sensitivity experiment were used to calculate the inhibition frequency of uredospore germination by employing the equation:

$$
\text { Inhibition }(\%)=\frac{\mathrm{G}_{\mathrm{c}}-\mathrm{G}_{\mathrm{i}}}{\mathrm{G}_{\mathrm{c}}} \times 100
$$

where, $G_{c}=$ Spores germinated in control treatment with DMSO and Tween 80; $G_{i}=$ Total germination of each observation.

\subsection{Effect of bis(N-R-Sulfonyldithiocarbimato)Zincate(II) Salts on the Epidemiological Components of the Coffee Leaf Rust and Asian Soybean Rust}

For the tests of coffee leaf rust, coffee seedlings of the Caturra variety (susceptible) at four months of age for the Asian soybean rust, soybean seedlings at 40 days of age were used.

Two in vivo experiments were performed in a completely randomized design with three replicates, each including three $3.0 \mathrm{dm}^{3}$ vessels with three plants. The treatments consisted of compounds $1 \mathrm{~A}, 2 \mathrm{~A}, 1 \mathrm{~B}, 2 \mathrm{~B}$ and the fungicide mancozeb. To evaluate the effect of the compounds on $H$. vastatrix (coffee leaf rust), the mancozeb was used at $1,000 \mu \mathrm{mol} \mathrm{L}{ }^{-1}$; for P. pachyrhizi (Asian soybean rust), $50 \mu \mathrm{mol} \mathrm{L}^{-1}$ of water and Haiten adjuvant (Arysta ${ }^{\circledR}$ ) at $0.1 \mathrm{~mL} \cdot \mathrm{L}^{-1}$ were used as two negative controls. Therefore, in both experiments, seven treatments and three replicates were conducted.

In the experiment with coffee leaf rust, chemical compounds were applied to the abaxial face of coffee plants, on the third and fourth pairs of leaves, using a $100 \mathrm{~mL}$ manual atomizer. After 24 hours, the plants were inoculated by sprinkling, using a DeVilbiss No. 15 , with a suspension at $10^{5}$ uredospores $\mathrm{mL}^{-1}$. They were kept for 48 hours in the dark, in a humid chamber at $22{ }^{\circ} \mathrm{C}$. After this period, the plants were incubated in a chamber at $22{ }^{\circ} \mathrm{C}$, with a 12-hour photoperiod. Evaluations were performed every two days, at the $18^{\text {th }}$ day after inoculation. The evaluated response variables were as follows: incubation period (IP); latent period (LP); spore production (SP); number of lesions sporulation (NLS); area under the disease progress curve (AUDPC).

In the experiment with the Asian soybean rust, chemical compounds were applied in the third pair of soybean plants, using a $100 \mathrm{~mL}$ manual atomizer. After 24 hours, the plants were inoculated by sprinkling, using a DeVilbiss No. 15, with a suspension at $10^{5}$ uredospores $\mathrm{mL}^{-1}$. They were kept for 48 hours in the dark, in a 
humid chamber at $22{ }^{\circ} \mathrm{C}$. After this period, the plants were incubated in a chamber at $22{ }^{\circ} \mathrm{C}$, with a 12 -hour photoperiod. Evaluations were performed each day starting on the fourth day after inoculation. The response variables obtained included LP; pustules $\mathrm{cm}^{-2}$; relative control efficiency (RCE) and AUDPC.

\subsection{Statistical Analysis}

The data obtained for the sensitivity experiment were transformed into $\log (\mathrm{x})$ and then submitted to $\operatorname{logistic}$ regression analysis to obtain the $90 \%$ inhibitory concentration $\left(\mathrm{IC}_{90}\right)$ of $H$. vastatrix or $P$. pachyrhizi uredospores. Data for the epidemiological components of coffee leaf rust and Asian soybean rust were submitted to analysis of variance. Then, the grouping of the mean values was performed through the Scott-Knott test. All analyses were performed on the R software using the DRC package (R Core Team, 2013; Ritz et al., 2015).

\section{Results}

All the 'in vitro' and 'in vivo' experiments were repeated at least three times with similar results.

\subsection{Synthesis of N-R-Sulfonyldithiocarbimate Potassium Salts}

The $N$-R-sulfonyldithiocarbimate potassium salts were characterized by infrared and the melting point and data are according to those found in the literature (Oliveira et al., 1999).

Four zinc(II) complexes salts (1A, 2A, 1B, and 2B) with $N$-R-sulfonyldithiocarbimates were synthesized and characterized by infrared and the melting point and data are according to those found in the literature (Oliveira et al., 2007; Alves et al., 2009; Amin et al., 2011; Tavares et al., 2012).

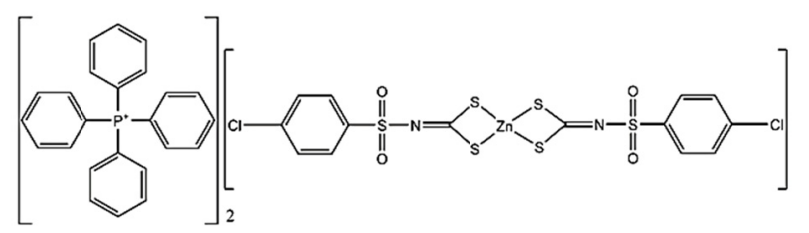

(1A)

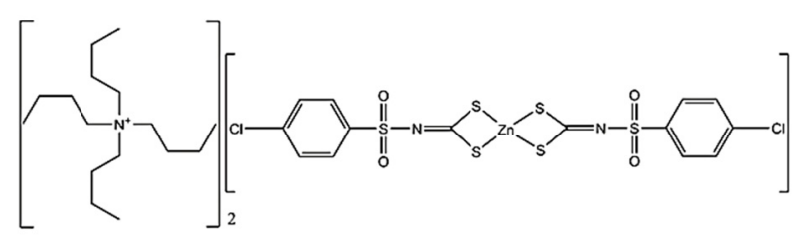

(1B)

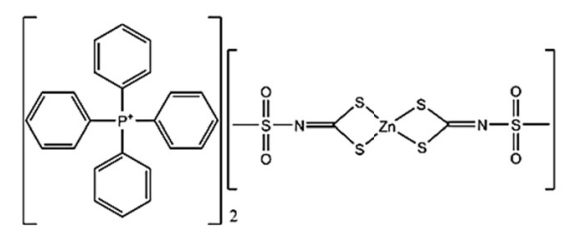

(2A)

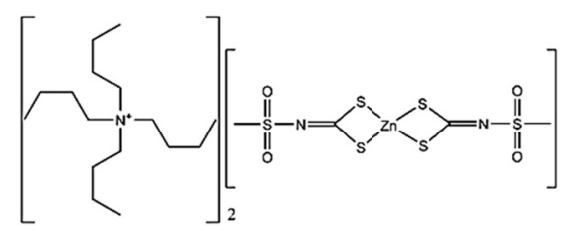

(2B)

Figure 1. Structural formula of the four ditiocarbimates sintetized. Tetraphenylphosphonium bis(4-chlorophenylsulfonyldithiocarbimate)zincate(II) (1A); tetraphenylphosphonium bis(methylsulfonyldithiocarbimate)zincate(II) (2A); tetrabutylammonium bis(4-chlorophenylsulfonyldithiocarbamate)zincate(II) (1B); and tetrabutylammonium bis(chlorophenylsulfonyldithiocarbimate)zincate(II) (2B)

\subsection{The Sensitivity of H. vastatrix and P. pachyrhizi to Zinc(II) Complexes Salts}

The curves of the logistic model were adjusted, and then the $\mathrm{IC}_{90}$ values were calculated for each compound (Figures 2 and 3). All the compounds synthetized in this study had inhibitory effects on $H$. vastatrix and $P$. pachyrhizi. 

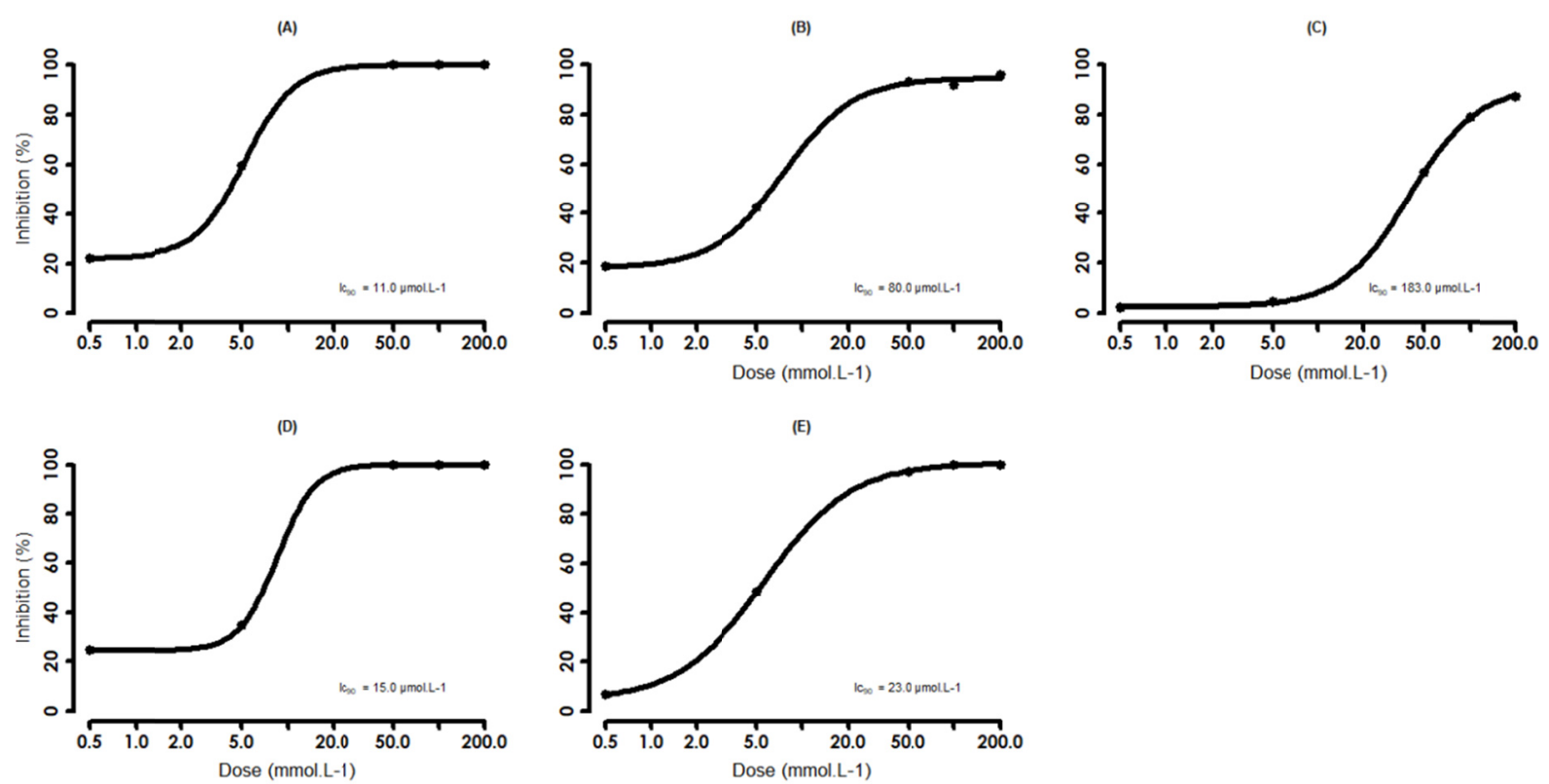

Figure 2. Inhibition of the germination of the uredopores of $H$. vastatrix and $\mathrm{IC}_{90}$. A: Mancozeb; B: Compund 1A; C: Compund 2A; D: Compund 1B; E: Compund 2B
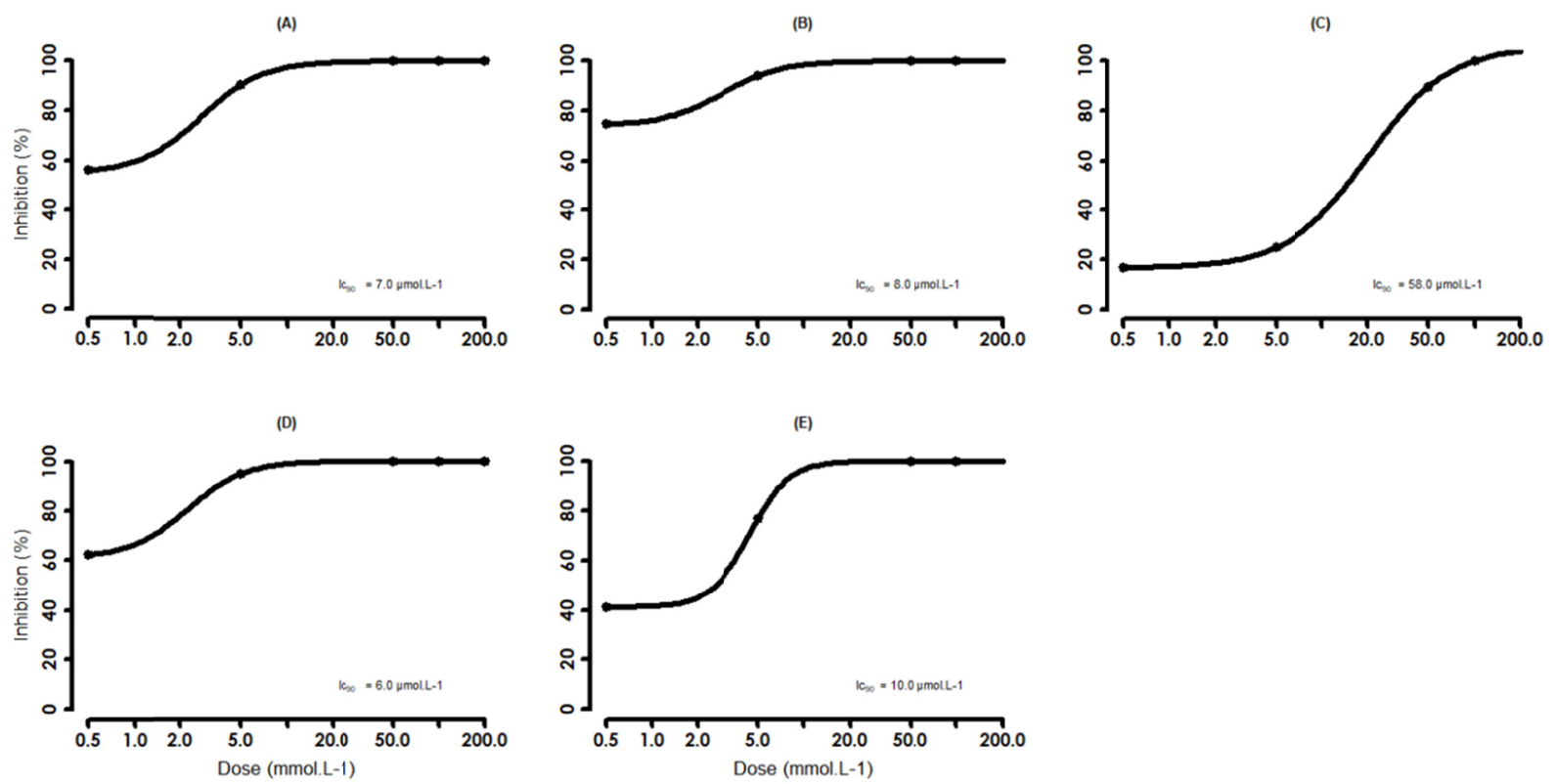

Figure 3. Inhibition of the germination of the uredopores of $P$. pachyrhizi and $\mathrm{IC}_{90}$. A: Mancozeb; B: Compund 1A; C: Compund 2A; D: Compund 1B; E: Compund 2B

For $H$. vastatrix, the lowest $\mathrm{IC}_{90}$ values were for positive control with mancozeb $\left(11.0 \mu \mathrm{mol} \mathrm{L} \mathrm{L}^{-1}\right)$. Among the

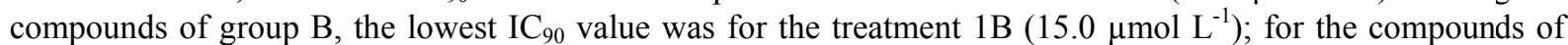
group $\mathrm{A}$, the lowest $\mathrm{IC}_{90}$ value was for treatment $1 \mathrm{~A}\left(80.0 \mu \mathrm{mol} . \mathrm{L}^{-1}\right)$. For the variable $\mathrm{IC}_{90 \mathrm{comb}}\left(\mathrm{mean} \mathrm{IC}_{90}\right.$ value of the two experiments), there was no significant difference between the treatments of group B compounds (1B, 2B) and mancozeb. However, the compounds of group B (1B, 2B) and mancozeb differed from those of the group A. There was a significant difference between compounds $1 \mathrm{~A}$ and 2A (Table 1). 
Table 1. Inibitory concentration $\left[\mathrm{IC}_{90}\left(\mu \mathrm{mol} \mathrm{L}^{-1}\right)\right]$ for $H$. vastatrix and Logístic model $\mathrm{f}(\mathrm{y})=\mathrm{c}$ $\backslash\{\mathrm{d}-\mathrm{c}\}\{1 \exp (\mathrm{b}(\backslash \log (\mathrm{x})-\backslash \log (\mathrm{e})))\}$

\begin{tabular}{|c|c|c|c|c|c|c|c|}
\hline \multirow{2}{*}{ Molecule } & \multicolumn{3}{|l|}{ Experiment 1} & \multicolumn{3}{|l|}{ Experiment 2} & \multirow{2}{*}{$\mathrm{IC}_{90 \text { comb }}$} \\
\hline & Parameters* & $\mathrm{R}^{2}$ & $\mathrm{IC}_{90}$ & Parameters* & $\mathrm{R}^{2}$ & $\mathrm{IC}_{90}$ & \\
\hline Mancozeb & $\mathrm{B}=-2.7 ; \mathrm{c}=2.2 ; \mathrm{d}=100.0 ; \mathrm{e}=0.005$ & 0.983 & 11.0 & $\mathrm{~B}=-2.7 ; \mathrm{c}=22.2 ; \mathrm{d}=100.0 ; \mathrm{e}=0.005$ & 0.973 & 11.0 & $11.0 \mathrm{C}$ \\
\hline $1 \mathrm{~A}$ & $\mathrm{~B}=-2.0 ; \mathrm{c}=3.1 ; \mathrm{d}=100.0 ; \mathrm{e}=0.026$ & 0.997 & 80.0 & $\mathrm{~B}=-1.2 ; \mathrm{c}=2.2 ; \mathrm{d}=100.0 ; \mathrm{e}=0.017$ & 0.987 & 102.0 & $91.0 \mathrm{~B}$ \\
\hline $1 \mathrm{~B}$ & $B=-3.5 ; c=24.6 ; d=100.0 ; e=0.008$ & 0.965 & 15.0 & $\mathrm{~B}=-3.5 ; \mathrm{c}=24.6 ; \mathrm{d}=100.0 ; \mathrm{e}=0.008$ & 0.933 & 15.0 & $15.0 \mathrm{C}$ \\
\hline $2 \mathrm{~A}$ & $\mathrm{~B}=-1.9 ; \mathrm{c}=10.1 ; \mathrm{d}=100.0 ; \mathrm{e}=0.060$ & 0.975 & 183.0 & $\mathrm{~B}=-1.9 ; \mathrm{c}=2.5 ; \mathrm{d}=100.0 ; \mathrm{e}=0.039$ & 0.998 & 120.0 & $151.0 \mathrm{~A}$ \\
\hline $2 \mathrm{~B}$ & $\mathrm{~B}=-1.5 ; \mathrm{c}=4.4 ; \mathrm{d}=100.0 ; \mathrm{e}=0.005$ & 0.952 & 23.0 & $B=-1.3 ; c=1.0 ; d=100.0 ; e=0.004$ & 0.997 & 21.0 & $22.0 \mathrm{C}$ \\
\hline
\end{tabular}

Note. $\mathrm{IC}_{90}$ : Inibitory concentration able to inhibit $90 \%$ of the germination of the uredospors of $H$. vastatrix; $\mathrm{IC}_{90}$ comb: Average values of the two replications of the experiments of $\mathrm{IC}_{90} ; \mathrm{R}^{2}$ : Determination coeficiente; (*): Parameters different of 0 for the $t$ test of Student $(p \leq 0.05)$. Similar letters in the column, do not differ significantly by the Scott-Knott test $(\mathrm{p} \leq 0.05)$.

For $P$. pachyrhizi, the lowest $\mathrm{IC}_{90}$ value in experiment 1 was $6.0 \mu \mathrm{mol} \mathrm{L}{ }^{-1}$ for compound $1 \mathrm{~B}$. In experiment 2 , the lowest value was $6.0 \mu \mathrm{mol} \mathrm{L}{ }^{-1}$ for mancozeb, followed by $8.0 \mu \mathrm{mol} \mathrm{L}-1$ for the compound $1 \mathrm{~B}$ (Table 2). The lowest doses of mancozeb, 1A, and $1 \mathrm{~B}$ inhibited more than $50 \%$ of uredospore germination (Table 2; Figure 3). The analysis of the $\mathrm{IC}_{90 \mathrm{comb}}$ of the compounds showed no significant differences between the treatments $1 \mathrm{~A}, 1 \mathrm{~B}$, $2 \mathrm{~B}$, and mancozeb (standard control) (Table 2). The lowest performance was observed for the compounds $2 \mathrm{~A}$, which differed significantly from other treatments.

Table 2. Inibitory concentration $\left[\mathrm{IC}_{90}\left(\mu \mathrm{mol} \mathrm{L} \mathrm{L}^{-1}\right)\right]$ of $P$. pachyrhizi uredospores and Logístic model $\mathrm{f}(\mathrm{y})=$ $c \backslash\{\mathrm{d}-\mathrm{c}\}\{1 \exp (\mathrm{b}(\backslash \log (\mathrm{x})-\backslash \log (\mathrm{e})))\}$

\begin{tabular}{|c|c|c|c|c|c|c|c|}
\hline \multirow{2}{*}{ Molecule } & \multicolumn{3}{|l|}{ Experiment 1} & \multicolumn{3}{|l|}{ Experiment 2} & \multirow{2}{*}{$\mathrm{IC}_{90 \text { comb }}$} \\
\hline & Parameters* & $\mathrm{R}^{2}$ & $\mathrm{IC}_{90}$ & Parameters* & $\mathrm{R}^{2}$ & $\mathrm{IC}_{90}$ & \\
\hline Mancozeb & $\mathrm{B}=-2.1 ; \mathrm{c}=54.8 ; \mathrm{d}=100.0 ; \mathrm{e}=0.002$ & 0.987 & 7.0 & $\mathrm{~B}=-2.0 ; \mathrm{c}=57.0 ; \mathrm{d}=100.0 ; \mathrm{e}=0.002$ & 0.995 & 6.0 & $6.5 \mathrm{C}$ \\
\hline $1 \mathrm{~A}$ & $\mathrm{~B}=-1.6 ; \mathrm{c}=72.4 ; \mathrm{d}=100.0 ; \mathrm{e}=0.022$ & 0.976 & 8.0 & $\mathrm{~B}=-1.5 ; \mathrm{c}=81.9 ; \mathrm{d}=100.0 ; \mathrm{e}=0.002$ & 0.994 & 9.0 & $8.5 \mathrm{~B}$ \\
\hline $1 \mathrm{~B}$ & $\mathrm{~B}=-2.1 ; \mathrm{c}=60.3 ; \mathrm{d}=100.0 ; \mathrm{e}=0.002$ & 0.923 & 6.0 & $\mathrm{~B}=-2.1 ; \mathrm{c}=60.3 ; \mathrm{d}=100.0 ; \mathrm{e}=0.002$ & 0.854 & 8.0 & $7.0 \mathrm{C}$ \\
\hline $2 \mathrm{~A}$ & $\mathrm{~B}=-1.4 ; \mathrm{c}=22.9 ; \mathrm{d}=100.0 ; \mathrm{e}=0.012$ & 0.998 & 62.0 & $\mathrm{~B}=-1.8 ; \mathrm{c}=16.8 ; \mathrm{d}=100.0 ; \mathrm{e}=0.017$ & 0.969 & 58.0 & $60.0 \mathrm{~A}$ \\
\hline $2 \mathrm{~B}$ & $\mathrm{~B}=-2.8 ; \mathrm{c}=41.2 ; \mathrm{d}=100.0 ; \mathrm{e}=0.004$ & 0.936 & 10.0 & $\mathrm{~B}=-3.0 ; \mathrm{c}=29.89 ; \mathrm{d}=100.0 ; \mathrm{e}=0.004$ & 0.893 & 9.0 & $9.5 \mathrm{C}$ \\
\hline
\end{tabular}

Note. $\mathrm{IC}_{90}$ : Inibitory concentration able to inhibit $90 \%$ of $P$. pachyrhizi uredospores germination; $\mathrm{IC}_{90}$ comb: average values of the two replications of the experiments of $\mathrm{IC}_{90} ; \mathrm{R}^{2}$ : Determination coeficiente; (*): Logistic model parameters different from 0 for the $t$ Student test $(\mathrm{p} \leq 0.05)$. Similar letters in the column, do not differ significantly by the Scott-Knott test $(\mathrm{p} \leq 0.05)$.

\subsection{Effect of Zinc(II) Complexes Salts on the Epidemiological Components of H. vastatrix}

Figure 4 shows the result of the epidemiological components when Caturra coffee plants were inoculated with $H$. vastatrix uredospores. The lowest PI for the control with water was 16 days; the highest values were achieved for the compounds mancozeb, 2A, and 2B, which lead to expressed symptoms at 24 days. All treatments differed from the control with water. The PI of the compounds did not differ significantly from the mancozeb (standard control) (Figure 4). 

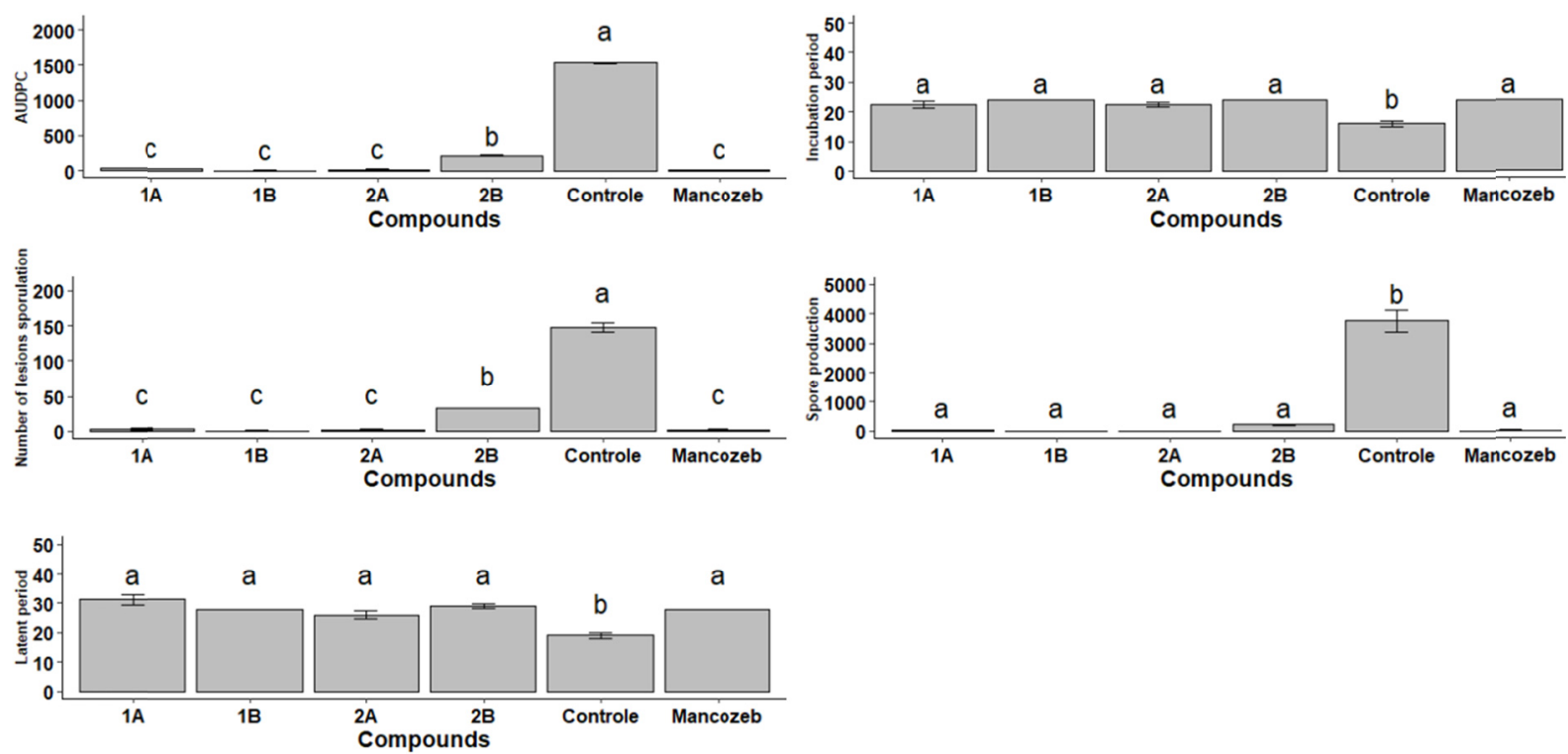

Figure 4. Epidemiological components of the Coffee leaf rust. Compounds "1" is 4-chlorophenyl group and "2" is methyl group. Compounds group " $\mathrm{B}$ " has the cation tetrabutylammonium and group " $\mathrm{A}$ " has the cation tetraphenylphosphonium. Similar letters do not differ significantly by the Scott-Knott $(p \leq 0.05)$ test

For the LP, the lowest value (19 days) was achieved for the control with water, differing significantly from the other treatments. There were no differences in LP values between the compounds and the mancozeb (Figure 4).

For the variable NLS, the control treatment with water had a mean value of 149.0 lesions/leaf, differing significantly from the other treatments. The mean value for the compound $2 \mathrm{~B}$ was estimated at 25.0 lesions/leaf, differing significantly from the treatments $1 \mathrm{~A}, 1 \mathrm{~B}, 2 \mathrm{~B}$, and mancozeb. The treatments $1 \mathrm{~A}, 1 \mathrm{~B}, 2 \mathrm{~B}$, and mancozeb did not differ significantly from each other (Figure 4).

Estimates for AUDPC showed that control with water differed significantly from the other treatments, with a mean value of $1,843.5$. Treatment $2 \mathrm{~B}$ had a mean value of 175.33 and differed significantly from the other compounds. The compounds1A, 1B, 2A, and mancozeb did not differ significantly from each other (Figure 4).

The results regarding the SP variable were significantly different between the control with water (mean of 3,770 uredospores $\mathrm{mL}^{-1}$ ) and the other treatments. The $2 \mathrm{~B}$ treatment had an estimated mean value of 145.60 uredospores $\mathrm{mL}^{-1}$ and differed significantly from the other compounds. Treatments 1A, 1B, 2A, and mancozeb did not differ significantly from each other (Figure 4).

\subsection{Effect of Zinc(II) Complexes Salts on the Epidemiological Components of P. pachyrhizi}

Figure 5 shows the results of the epidemiological components when Caturra coffee plants were inoculated with $P$. pachyrhizi uredospores. The results of treatments $1 \mathrm{~B}$ and $2 \mathrm{~B}$ were not considered. Data from treatments $1 \mathrm{~B}$ and 2B were impaired by the expression of phytotoxicity symptoms in soybean leaflets, 24 hours after applying the treatments, at $50 \mu \mathrm{mol} \mathrm{L}^{-1}$. The treatments $1 \mathrm{~A}, 2 \mathrm{~A}$, and mancozeb showed no damage to the soybean leaflets at the concentrations used (Figure 5).

The LP for the control with water was nine days. The appearance of symptoms was later in the $2 \mathrm{~A}$ treatment (mean of 21 days), and the estimate for compound 1A was 12 days. Since lesions were not observed in plants treated with mancozeb, the LP was not estimated.

For the variable pustules per $\mathrm{cm}^{2}$, the control with water had a mean value of 18.30 pustules $/ \mathrm{cm}^{2}$, differing significantly from the other treatments. The mean value for the compound $2 \mathrm{~A}$ was estimated at 0.8 pustules $/ \mathrm{cm}^{2}$ and for mancozeb, 0.0; these treatments did not differ significantly from each other (Figure 5).

Regarding the AUDPC variable, the control with water had a mean value of 75.8 and differed significantly from the other treatments. The compound $1 \mathrm{~A}$ had an estimated mean value of 43.50 and was significantly different between the treatments $2 \mathrm{~A}(4.16)$ and mancozeb (0.0). Compound 2A and mancozeb did not differ significantly from each other (Figure 5). 

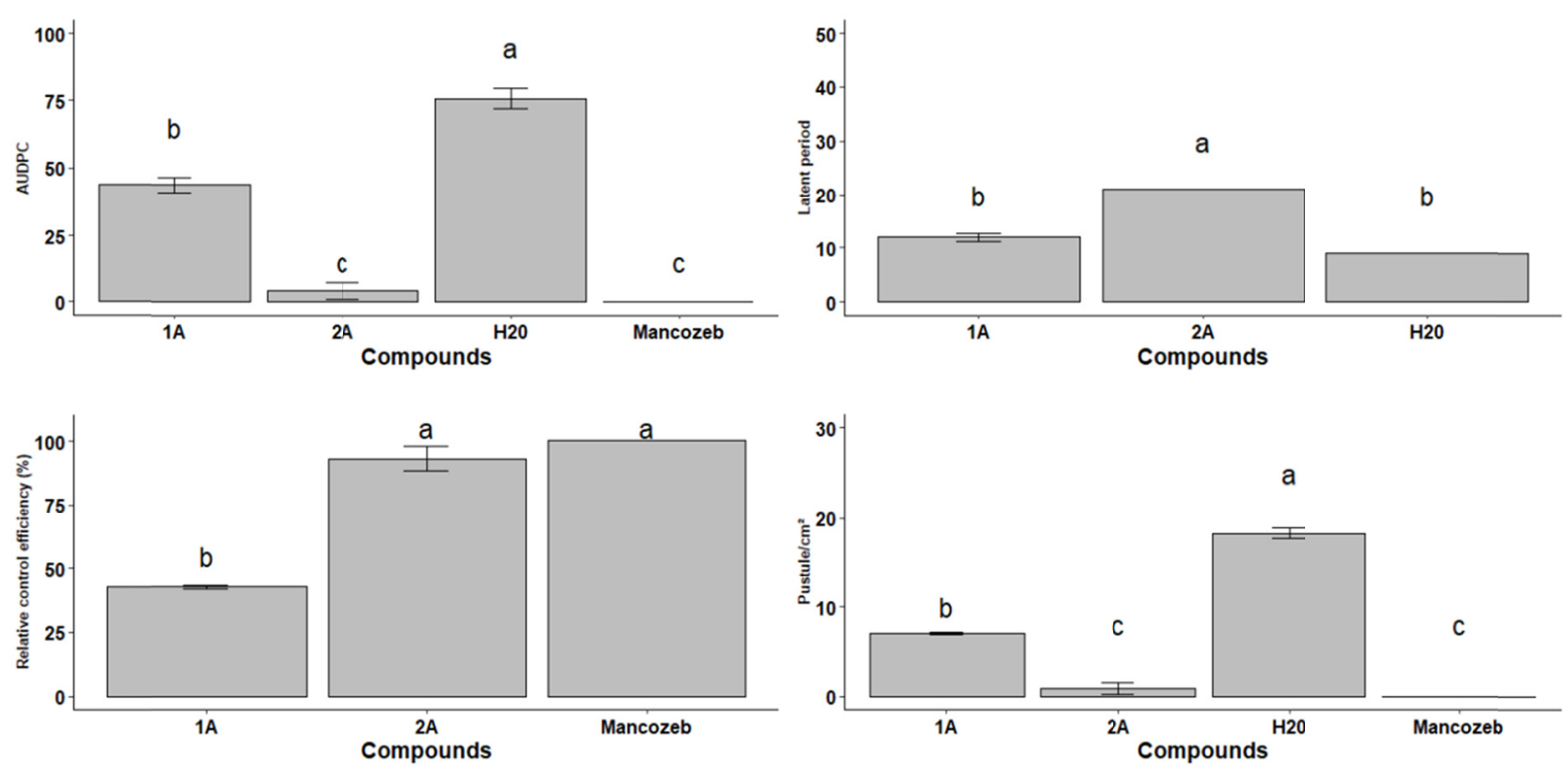

Figure 5. Epidemiological components of the Asian soybean rust. Compounds " 1 " is 4-chlorophenyl group and "2" is methyl group. Compounds group " $\mathrm{B}$ " has the cation tetrabutylammonium and group "A" has the cation tetraphenylphosphonium. Similar letters do not differ significantly by the Scott-Knott $(p \leq 0.05)$ test

The compound 1A had the smallest RCE, with values lower than the control treatment $\left(42.7 \%\right.$ pustule/ $\left./ \mathrm{cm}^{2}\right)$. There was a significant difference between the compound 2A (92.9\%) and mancozeb (100.0\%) in the disease control. However, compound 2A and mancozeb did not differ significantly from each other (Figure 5).

\section{Discussion}

All the zinc(II) complexes salts (1A, 2A, 1B, and 2B) were able to inhibit the uredospore germination of $H$. vastatrix and $P$. pachyrhizi when compared with the standard treatment mancozeb and were more efficient when compared to the results obtained by Vidigal et al. (2019). In this study, the lowest $\mathrm{IC}_{90}$ values for the compound 1B were $15 \mu \mathrm{mol} \mathrm{L}^{-1}$ for $H$. vastatrix and $6.0 \mu \mathrm{mol} \mathrm{L}{ }^{-1}$ for P. pachyrhizi. The lowest $\mathrm{IC}_{90}$ values found by Vidigal et al. (2019) for the bis(triphenylphosphino)(4-isopropylphenylsulfonyldithiocarbimate)nickel(II) were $405 \mu \mathrm{mol} \mathrm{L} \mathrm{L}^{-1}$ for $H$. vastatrix and for the bis(triphenylphosphino)(butylsulfonyldithiocarbimate)nickel(II) were $280 \mu \mathrm{mol} \mathrm{L}^{-1}$ for P. pachyrhizi.

For $H$. vastatrix, the $\mathrm{IC}_{90 \mathrm{comb}}$ of the curves of the two experiments showed that the treatments $1 \mathrm{~B}$ and $2 \mathrm{~B}$ had a performance similar to the control with mancozeb. However, compounds group A were less effective in inhibiting $H$. vastatrix germination, when compared with the compounds of group B and mancozeb. Analysis of the $\mathrm{IC}_{90 \text { comb }}$ values showed that the compounds $1 \mathrm{~A}, 1 \mathrm{~B}$, and $2 \mathrm{~B}$ were capable of inhibiting P. pachyrhizi sporulation in a similar way to the standard control with mancozeb. Treatment with the compound $2 \mathrm{~A}$ differed from the others and was the least active. However, $100 \%$ of spores were inhibited from $100 \mu \mathrm{mol} \mathrm{\textrm {L } ^ { - 1 }}$. The fungitoxic action can explain the performance variation of the zinc(II) complexes salts in the spore germination. Physiological and genetic factors may influence the ability of the fungus to respond to stresses caused by fungicides. Usually, fungi respond to the stress caused by fungicides from the altered target site, detoxification of fungicide, over-expression of the target with increased fungicide compounds in the cytosol, and efflux of fungicides from the target site (Kretschmer et al., 2009).

Having the ability to inhibit the germination of a fungus in vitro assays does not mean that the compound is promising for controlling a disease. A hydrophobicity of the compounds diffused in agar may affect performance. The physical-chemical compound interactions with plant cells may also present phytotoxic effects. In this sense, the selection of new compounds using epidemiological components is a useful approach in the early stages of development of new fungicides because the new compounds are challenged at the time of interaction with the host. The selection of new fungicides based on the analysis of epidemiological components may contribute to the decision about application dose, application methods, mobility in plant, role in crop protection, breadth of activity, interactions with adjuvants, and control efficiency disease (Zambolim et al., 2014). 
The results of the epidemiological components for both diseases showed that bis(N-R-sulfonyldithiocarbimato)zincate(II) salts had an efficacy similar to the positive control with mancozeb. The compounds 2A, 1B, and 1A stood out in the analyses. The highest PI and LP values and lowest SP values were obtained for these compounds, suggesting that these compounds can efficiently reduce disease cycles (Leclerc et al., 2014).

The higher estimated values of the epidemiological components IP and LP concomitantly with lower SP value found in this study suggest that the use of that bis(N-R-sulfonyldithiocarbimato)zincate(II) salts may reduce the progress rate (r) of the coffee leaf rust epidemic, and most likely have a lower impact on coffee productivity (Zambolim, 2016). On the other hand, the 2B compound had lower estimated LP values combined with higher SP values for coffee leaf rust. Thus, the compound $2 \mathrm{~B}$ should be disregarded in new studies since the epidemiological components indicate risks of inefficiency in the control of coffee leaf rust. When chemical control is inefficient, the disease causes defoliation in coffee plants and consequently reduces the yields of crops in the following year (Souza et al., 2011; Talhinhas et al., 2017).

The results of the variables LP, pustules $/ \mathrm{cm}^{2}, \mathrm{RCE}$, and AUDPC showed that treatment with compound 1A was not efficient to control the Asian soybean rust. On the other hand compound $2 \mathrm{~A}$ and mancozeb were efficient and did not differ significantly from each other. However, the efficiency of compound 1A may increase at higher doses. In the present study, the bis(N-R-sulfonyldithiocarbimato)zincate(II) salts were used in the molar ratio to standardize the number of compounds in each treatment. Thus, the molar concentration of each compound used in the experiment $\left(50 \mu \mathrm{mol} \mathrm{L}{ }^{-1}\right)$ was equivalent to a reduction of 175 times concerning the recommendation of $3.75 \mathrm{~kg}$ of the active ingredient mancozeb per hectare.

Compounds $1 \mathrm{~B}$ and 2B caused phytotoxicity in soybean leaflets. However, there were no visible anomalies in the leaf tissues submitted to treatment with compounds $1 \mathrm{~A}$ and $2 \mathrm{~A}$. The phytotoxicity property of the compounds group B may be related to the presence of different counter-ions. Group A contains tetraphenylphosphonium, and group B contains tetrabutylammonium. Besides, phytotoxicity may be related to the interaction of ammonium ion in leaf tissues. The plant cells absorb the ammonium ion passively; however, if the absorption levels are higher than those of metabolization, the intoxication of the leaf tissues may occur (Barker, 1999). Usually, damage caused by the ammonium ion affects photosynthetic processes, ATP synthesis, and the electron transport chain (Opanasenko \& Vasyukhina, 2009).

\section{Conclusion}

The salts "bis(N-R-sulfonyldithiocarbimato)zincate(II)" are an option for the control of coffee leaf rust and Asian soybean rust; their efficiency is comparable to the standard product mancozeb. For Asian soybean rust, only the compound $2 \mathrm{~A}$ was efficient for the control. Compounds $1 \mathrm{~A}, 2 \mathrm{~A}$, and $1 \mathrm{~B}$ were adequate for the control of coffee leaf rust.

\section{References}

Alves, L. C., Rubinger, M. M. M., Lindemann, R. H., Perpétuo, G. J., Janczak, J., Miranda, L. D. L., ... Oliveira, M. R. L. (2009). Syntheses, crystal structure, spectroscopic characterization and antifungal activity of new N-R-sulfonyldithiocarbimate metal complexes. Journal of Inorganic Biochemistry, 103, 1045-1053. https://doi.org/10.1016/j.jinorgbio.2009.04.018

Amin, R. S., Oliveira, M. R. L., Janczak, J., Rubinger, M. M. M., Vieira, L. M. M., Alves, L. C., \& Zambolim, L. (2011). Syntheses, characterization, crystal structure and antifungal activity of four tetraphenylphosphonium bis(N-R-sulfonyldithiocarbimato)zincat(II) salts. Polyhedron, 30, 683-689. https://doi.org/10.1016/j.poly.2010.12.003.

Barker, A. V. (1999). Foliar ammonium accumulation an index of stress in plants. Commun Soil Sci Plant Anal, 30, 167-174. https://doi.org/10.1080/00103629909370193

Bottega, F. C., Oliveira, M. R. L., Garcia, C. V., \& Menezes, D. C. (2013). Syntheses, characterization and antifungal activity of tris(1,10-phenanthroline) iron(ii) bis(N-R-ulfonyldithiocarbimate)zincate(ii). Quimica Nova, 803-807. https://doi.org/10.1590/S0100-40422013000600011

CONAB. (2019). Retrieved from https://www.conab.gov.br/info-agro/safras/graos/boletim-da-safra-de-grãos

Godoy, C. V., Utiamada, C. M., Meyer, M. C., Campos, H. D., Forcelini, C. A., Pimenta, C. B., \& Jaccoud Filho, D. S. (2016). Eficiência de fungicidas multissitios no controle da ferrugem-asiática-da-soja, Phakopsora pachyrhizi, na safra: Resultados sumarizados dos ensaios cooperativos Embrapa (pp. 1-7). 
Kretschmer, M., Leroch, M., Mosbach, A., Walker, A., Fillinger, S., Mernke, D., ... Hahn, M. (2009). Fungicide-driven evolution and molecular basis of multidrug resistance in field populations of the grey mould fungus Botrytis cinerea. PLoS Pathog, 5(12). https://doi.org/10.1371/journal.ppat.1000696

Leclerc, M., Doré, T., Gilligan, C. A., Lucas, P., \& Filipe, J. A. N. (2014). Estimating the delay between host infection and disease (incubation period) and assessing its significance to the epidemiology of plant diseases. PLoS ONE, 9(1). https://doi.org/10.1371/journal.pone.0086568

Oliveira, A. A., Oliveira, M. R. L., Rubinger, M. M. M., Pilóa, E. L., Meneses, D. C., \& Zambolim, L. (2015). bis(4-fluorophenylsulfonyldithiocarbimato) zincate(ii) salts: New antifungals for the control of Botrytis blight. Quimica Nova, 757-761. https://doi.org/10.5935/0100-4042.20150075

Oliveira, M. R. L., \& de Bellis, V. M. (1999). Preparation of novel cobalt(III) complexes with dithiocarbimates derived from sulfonamides. Transition Metal Chemetry, 24, 127-130.

Oliveira, M. R. L., Perpétuo, G. J., Janczak, J., \& Rubinger, M. M. M. (2007). Synthesis, structural and spectroscopic characterization of novel zinc (II) complexes with N-methylsulfonyldithiocarbimato and N-methylsulfonyltrithiocarbimato ligands. Polyhedron, 26, 163-168. https://doi.org/10.1016/j.poly.2006. 08.002

Opanasenko, V. K., \& Vasyukhina, L. A. (2009). Synergism of ammonium and palmitic acid in uncoupling of electron transfer and ATP synthesis in chloroplasts. Biochemical, 74, 643-647. https://oi.org/10.1134/ s000629790906008x.

Ponce, R. B. O., Zambolim, L., Fortunato, A. A., \& Queiroz, L. F. (2019). High risk fungicides combined to low risk can be a new strategy for management of Asian soybean rust. Journal of Agricultural Science, 11, 148-158. https://doi.org/10.5539/jas.v11n1p149

R Core Team. (2013). R: A language and environment for statistical computing. R Foundation for Statistical Computing, Vienna, Austria.

Reis, E. M., Zanata, M., \& Reis, A. C. (2021). Addition of Mancozeb to DMI + QoI, and SDHI + QoI Co-formulations Improving Control of Asian Soybean Rust. Journal of Agricultural Science, 13(1), 195-201. https://doi.org/10.5539/jas.v13n1p195

Ritz, C., Baty, F., Streibig, J. C., \& Gerhard, D. (2015). Dose-response analysis using R. PLoS ONE, 12, 1-13. https://doi.org/10.1371/journal.pone.0146021

Schmitz, H. K., Medeiros, C. A., Craig, I. R., \& Stammler, G. (2014). Sensitivity of Phakopsora pachyrhizi towards quinone-outside-inhibitors and demethylation-inhibitors, and corresponding resistance mechanisms. Pest Management Science, 70, 378-388. https://doi.org/10.1002/ps.3562

Simões, K., Hawlik, A., Rehfus, A., Gava, F., \& Stammler, G. (2018). First detection of a SDH variant with reduced SDHI sensitivity in Phakopsora pachyrhizi. J. Plant Dis Prot, 125, 21-26. https://doi.org/10.1007/ s41348-017-0117-5

Sousa, T. V., Caixeta, E. T., Alkimim, E. R., Oliveira, R., Pereira, A. C. B., Alves, A., ... Sakiyama, N. S. (2017). Molecular markers useful to discriminate Coffea arabica cultivars with high genetic similarity. Euphytica, 213, 75. https://doi.org/10.1007/s10681-017-1865-9

Souza, A. F., Zambolim, L., De Jesus Júnior, V. C., \& Cecon, P. R. (2011). Chemical approaches to manage coffee leaf rust in drip irrigated trees. Australas. Plant Pathol., 40, 293-300. https://doi.org/10.1007/ s13313-011-0046-X

Talhinhas, P., Batista, D., Diniz, I., Vieira, A., Silva, D. N., Loureiro, A., ... Silva, M. C. (2017). The coffee leaf rust pathogen Hemileia vastatrix: One and a half centuries around the tropics. Molecular Plant Pathology, 18, 1039-1051. https://doi.org/10.1111/mpp.12512

Tavares, E. C., Oliveira, M. R. L., Janczack, J., Vieira, C. G., Alves, L. C., Castro, R. A., ... Rubinger, M. M. M. (2012). Syntheses, structural and spectroscopic characterization of novel zinc (II)-bis(trithiocarbimato)complexes and bis( $N$-methylsulfonyldithiocarbimate)-sulfide. Polyhedron, 31, 494-501. https://doi.org/10.1016/j.poly.2011.10.004

Twizeyimana, M., \& Hartman, G. L. (2017). Sensitivity of Phakopsora pachyrhizi isolates to fungicides and reduction of fungal infection based on fungicide and timing of application. Plant Disease, 101, 121-128. https://doi.org/10.1094/PDIS-04-16-0552-RE 
Vidigal, A. E. C., Rubinger, M. M. M., Queiroz, L. F., Silva, L. F., Zambolim, L., Guilardi, S., ... Oliveira, M. R. L. (2019). Nickel complexes with phosphines and N-R-sulfonyldithiocarbimates ligands: New antifungals for the control of Hemileia vastatrix and Phakopsora pachyrhizi. Inorganica Chimica Acta, 486, 724-732. https://doi.org/10.1016/j.ica.2018.11.037

Yorinori, J. T., Paiva, W. M., Frederick, R. D., Costamilan, L. M., Bertagnolli, P. F., Hartman, G. E., ... Nunes, J. (2005). Epidemics of Soybean Rust (Phakopsora pachyrhizi) in Brazil and Paraguay from 2001 to 2003. J. Plant Disease, 89, 675-677. https://doi.org/10.1094/PD-89-0675

Zambolim, L. (2016). Current status and management of coffee leaf rust in Brazil. Trop Plant Pathol., 41, 1-8. https://doi.org/10.1007/s40858-016-0065-9

Zambolim, L. (2008). Tipos de fungicidas empregados no controle de doenças de plantas: Produtos fitossanitários (pp. 263-347). Universidade Federal de Viçosa, Viçosa, Minas Gerais.

Zambolim, L., \& Caixeta, E. T. (2018). Ferrugem. In L. Zambolim \& B. M. Brenes (Eds.), Doenças do café no Brasil (Enfermedades del café en Central-America) (Vol. 1, pp. 17-48). Universidade Federal de Viçosa, Viçosa, MG.

Zambolim, L., Picanço, M. C., \& Silva, A. A. (2014). O que Engenheiros Agrônomos devem saber para orientar produtos Fitossanitários (4th ed., pp. 437-494). Universidade Federal de Viçosa, Viçosa, MG.

\section{Copyrights}

Copyright for this article is retained by the author(s), with first publication rights granted to the journal.

This is an open-access article distributed under the terms and conditions of the Creative Commons Attribution license (http://creativecommons.org/licenses/by/4.0/). 